Dr Agata Bury

Chair of Economics

The School of Finance and Computer Sciences in Lódź

Faculty of Economics in Kalisz

agata.bury@interia.pl

dr Piotr Bury

Institute of Economics

University of Human and Natural Sciences in Kielce

Faculty of Management and Administration

pibury@onet.pl

\title{
LOCAL FINANCE IN POLAND IN VIEW OF THE EUROPEAN CHAR- TER OF LOCAL SELF-GOVERNMENT
}

\begin{abstract}
Local government in Poland exists already 18 years, half of it on the all three tiers of the administrative division i.e. in gminas, poviats and voivodships. The period is long enough to look critically at principles of its activity.

The goal of this paper is to analyze the compatibility of the Polish local government financial system with the guidelines of The European Charter of Local Self-Government, which was ratified by Poland in full in 1993. After a short description of general principles of local government the area of local government finance is discussed, especially the problem of so-called own revenues.

The conclusions could be used to show directions of changes in polish local finance, as well as to serve as guidelines for Ukrainian democracy in creating its local selfgovernments.

The topic of the paper seems to be especially current in the context of Ukraine's efforts to access the European Union. Sooner or later, Ukraine also will have to face with the provisions of The European Charter of Local Self-Government.
\end{abstract}

Key words: State and Local Taxation, Subsidies, and Revenues 